\title{
Characterization of Soluble Fibronectin Binding to Bacille Calmette-Guérin
}

\author{
By JABER ASLANZADEH, ${ }^{1}$ ERIC J. BROWN, ${ }^{2}$ SHAWN P. QUILLIN, \\ JULIE K. RITCHEY ${ }^{1}$ AND TIMOTHY L. RATLIFF ${ }^{1 *}$ \\ ${ }^{1}$ Washington University School of Medicine and the Jewish Hospital of St Louis, \\ Department of Surgery, Division of Urology, 216 South Kingshighway, St Louis, \\ Missouri 63110, USA \\ ${ }^{2}$ Washington University School of Medicine, Department of Medicine and Microbiology and \\ Immunology, St Louis, Missouri 63110, USA
}

(Received 1 March 1989; revised 24 June 1989; accepted 29 June 1989)

Fibronectin (FN), a $420 \mathrm{kDa}$ glycoprotein, consists of two similar subunits linked by a disulphide bond near the C-terminal end. $\mathrm{FN}$ is present in soluble and matrix forms in various body fluids and tissues and has been shown to bind to a variety of organisms. We characterized the conditions required for ${ }^{125} \mathrm{I}-\mathrm{FN}$ binding to Bacille Calmette-Guérin (BCG). The binding was dose-dependent, reached saturation within $3 \mathrm{~min}$, and was essentially irreversible for at least $24 \mathrm{~h}$ under optimal binding conditions at $\mathrm{pH} 6.0$. In contrast, the binding was reversible ( $>90 \%$ in $24 \mathrm{~h}$ ) when the $\mathrm{pH}$ was increased to $10 \cdot 0$. Scatchard analysis of the dose-response experiments produced a straight line, suggesting the presence of a single class of $\mathrm{FN}$ receptor on BCG. ${ }^{125} \mathrm{I}-\mathrm{FN}$ binding was trypsin-sensitive, suggesting that the BCG-binding molecule is a protein. The number of FN receptors was determined to be $8000-15000$ per bacterium. ${ }^{125}$ I-FN binding was $\mathrm{pH}$ dependent, with maximal binding at acidic $\mathrm{pH} .{ }^{125} \mathrm{I}-\mathrm{FN}$ binding was sensitive to the presence of $\mathrm{NaCl}$, with $0.08 \mathrm{M}-\mathrm{NaCl}$ inhibiting binding by $85 \%$. These data demonstrate that soluble FN binds to a trypsin-sensitive cell-surface component of BCG in an essentially irreversible manner.

\section{INTRODUCTION}

Fibronectin (FN), a $420 \mathrm{kDa}$ glycoprotein, consists of two similar subunits linked by a disulphide bond near the C-terminal end. It is present in soluble and matrix forms in various body fluids and tissues (Mosher, 1980). FN binds to specific receptors on eukaryotic cells such as macrophages and polymorphonuclear leucocytes (Wirth \& Kierszenbaum, 1984; Proctor et al., $1982 b$ ). FN interacts with macromolecules such as collagen, fibrin, heparin, heparin sulphate, dextran sulphate, DNA, actin and hyaluronic acid. In addition, $\mathrm{FN}$ has been reported to bind to bacteria including Staphylococcus aureus, group A, C, and G streptococci, Treponema pallidum, Escherichia coli and Salmonella dublin (Hynes \& Yamad, 1982; Speziale et al., 1984; Proctor et al., 1982a).

The interaction between FN, both soluble and matrix, and staphylococci has been studied extensively by many investigators. It has been demonstrated that a $29 \mathrm{kDa} F N$ fragment at the $\mathrm{NH}_{2}$-terminus of the molecule contains the staphylococcal binding site. The binding is mediated through a bacterial surface protein with an apparent molecular mass of $210 \mathrm{kDa}$ (Fröman et al., 1987). The binding is believed to be specific, time-dependent and irreversible, and occurs to

\footnotetext{
* To whom reprint requests should be addressed at the Department of Surgery, the Jewish Hospital of St Louis, 216 South Kingshighway, St Louis, Missouri 63110, USA.
}

Abbreviations: BCG, Bacille Calmette-Guérin; FN, fibronectin. 
heat-killed as well as to live organisms. Finally, the binding is saturable with as many as $\mathbf{3 0 0 0 0}$ FN molecules per cell (Proctor et al., 1982a).

Bacille Calmette-Guérin (BCG) have been shown to be the treatment of choice for superficial bladder cancer (Mori et al., 1986; Catalona et al., 1987). Ratliff et al. (1987) showed that in a mouse model the binding of BCG to the FN exposed on the bladder urothelium was an important initial step for BCG-mediated antitumour activity. In vitro experiments examining the interaction between FN and BCG revealed that BCG bound to FN-coated surfaces through a trypsin-sensitive bacterial surface protein. The binding was dose-dependent and could be blocked with antibody specific to FN (Ratliff et al., 1988).

While intravesical BCG appears to be the best available treatment for superficial bladder tumours, the $70 \%$ response rate has room for improvement. It was hypothesized that at least some of the failures may have resulted from poor attachment of BCG to the bladder wall. One potential reason for poor BCG attachment may be the presence of soluble $\mathrm{FN}$ in the bladder. Animal studies demonstrated that soluble FN prevented the binding of BCG to the matrix FN exposed on the bladder wall (unpublished). In this report we describe the conditions required for the interaction of BCG and soluble FN.

\section{METHODS}

Chemicals. All chemicals were purchased from Sigma and were reagent grade unless otherwise stated.

Bacteria. BCG were obtained from Armand Frappier, Quebec, Canada, as a lyophilized preparation containing $10^{7}$ c.f.u. $\mathrm{mg}^{-1}$ (manufacturer's specification). Before use, BCG was cultured in Youman's medium for $5 \mathrm{~d}$ at $37^{\circ} \mathrm{C}$. The bacteria were harvested by centrifugation and resuspended in buffer to produce approximately $7 \times 10^{8}$ c.f.u. $\mathrm{ml}^{-1}$ (determined by standard curves plotting $\mathrm{OD}_{520}$ vs c.f.u.).

Preparation of ${ }^{125}$ I-labelled FN. Human plasma FN was purified as described by Pommier et al. (1984). The purified FN, $1.5 \mathrm{mg} \mathrm{ml}^{-1}$, was labelled for $15 \mathrm{~min}$ with $1 \mathrm{mCi}(37 \mathrm{MBq}){ }^{125} \mathrm{INa}$ (Amersham) in a test-tube precoated with $200 \mu \mathrm{g}$ Iodo-Gen (1,3,4,6-tetrachloro-3,6-diphenylglycouril). The labelled FN was then separated from unbound ${ }^{125}$ I by chromatography on a $10 \mathrm{ml}$ bed volume Sephadex $\mathrm{G} 25$ column. The specific activities of the labelled FN preparations were routinely between $10^{6}$ and $10^{7}$ c.p.m. $\mu \mathrm{g}^{-1}$.

Binding assay. The binding assay was performed as described by Proctor et al. (1982a). Six micrograms of ${ }^{125} \mathrm{I}$ FN (unless otherwise stated) was added to $1.5 \mathrm{ml}$ volume microcentrifuge tubes (Eppendorf) precoated for $2 \mathrm{~h}$ with $1 \mathrm{ml}$ of $1 \mathrm{mg} \mathrm{ml}^{-1}$ human serum albumin and containing $7 \times 10^{6}$ BCG suspended in $1.0 \mathrm{ml} 0.1 \mathrm{M}$-Tris buffer, $\mathrm{pH} 6.0$, unless noted otherwise. The ${ }^{125} \mathrm{I}-\mathrm{FN}$ was mixed with either $300 \mu \mathrm{l}$ unlabelled $\mathrm{FN}\left(1 \mathrm{mg} \mathrm{ml}^{-1}\right)$ or $300 \mu \mathrm{l}$ of the appropriate buffer to determine non-specific and total binding, respectively. Specific binding was ascertained by subtracting non-specific from total binding. The reaction mixtures were incubated for $1 \mathrm{~h}$ at $22{ }^{\circ} \mathrm{C}$ unless noted otherwise. After incubation, the microcentrifuge tubes containing the reaction mixtures were centrifuged at $10000 \mathrm{~g}$ for $3 \mathrm{~min}$ in a Beckman Microcentrifuge B. The supernatant, containing free radiolabelled FN, was carefully removed. The microcentrifuge tubes were sliced and the pellets containing the radiolabelled FN bound to BCG were analysed for radioactivity. Control experiments using ${ }^{125} \mathrm{I}-\mathrm{FN}$ without bacteria produced background counts of $<500$ c.p.m.

Effect of time on $F N$ binding to $B C G$. To determine whether FN binding to BCG was saturable, binding assays were carried out as indicated above, except that the BCG/FN mixtures were incubated for 3, 5, 10,20 and $60 \mathrm{~min}$. After incubation, BCG were harvested, and specific FN binding was determined for each time point.

Effect of temperature on FN binding to BCG. The binding assay was carried out at 4,22 and $37^{\circ} \mathrm{C}$. The BCG suspensions were preincubated at the appropriate temperature for $1 \mathrm{~h}$ to equilibrate the metabolic rate. Samples were taken after 1,3 or $5 \mathrm{~h}$ of incubation.

Effect of $p H$ on FN binding to BCG. The binding assay was conducted as described above. Bacteria were suspended in $1 \mathrm{ml}$ of appropriate buffer, with a pH range of 3-10 (ammonium acetate buffer for $\mathrm{pH} \mathrm{3-6}$ and Tris for $\mathrm{pH} 7-10$ ). Total and non-specific binding was obtained for each $\mathrm{pH}$ by adding $300 \mu$ lof either corresponding buffer or unlabelled FN diluted in the appropriate buffer.

Effect of $\mathrm{NaCl}$ on $\mathrm{FN}$ binding to $\mathrm{BCG}$. Binding assays were carried out as described above, utilizing BCG suspended in buffers supplemented with $\mathrm{NaCl}$ concentrations ranging from 0 to $3.0 \mathrm{M}$.

Reversibility of the $B C G / F N$ interaction. The binding assay was performed at $\mathrm{pH} 6.0$ as described above, except that BCG was irradiated [ $5000 \mathrm{rad}(50 \mathrm{~Gy})$ for $6 \mathrm{~min}$ ] to prevent growth of bacteria and elaboration of proteases (Proctor et al., 1982a). After centrifugation and removal of unbound radiolabelled FN, half of the samples were resuspended in $1.3 \mathrm{ml}$ of the appropriate Tris buffer and the other half were resuspended in $1.3 \mathrm{ml}$ of the same buffer containing $300 \mu \mathrm{g}$ unlabelled FN. The bacterial suspensions were then incubated for $0 \mathrm{~min}, 5 \mathrm{~min}, 15 \mathrm{~min}$, $1 \mathrm{~h}, 5 \mathrm{~h}$ or $24 \mathrm{~h}$ at either $\mathrm{pH} 6.0$ or 10.0 , after which specific binding was determined. 
Saturability of the binding. BCG were suspended in buffer ( $\mathrm{pH} \mathrm{6.0)}$. The binding assay was conducted as described above, using an increasing concentration of ${ }^{125} \mathrm{I}-\mathrm{FN}(0-30 \mu \mathrm{g})$. The data obtained were plotted by the method of Scatchard (1949) and the number of fibronectin molecules bound per bacterium and apparent association constant were calculated from the $x$-axis intercept and slope, respectively.

Effect of trypsin on FN binding to BCG. BCG were incubated for $30 \mathrm{~min}$ in a suspension of trypsin $(500 \mu \mathrm{g}$ $\mathrm{ml}^{-1}$ )/EDTA at $37^{\circ} \mathrm{C}$. Trypsin inhibitor was added and the bacteria were washed in acetate buffer, $\mathrm{pH} 6 \cdot 0$, three times. These bacteria were subsequently utilized in the FN binding assay as described above.

\section{RESULTS}

Fig. 1 illustrates the effect of length of incubation on the specific binding of BCG to FN. Binding reached equilibrium rapidly $(<3.0 \mathrm{~min})$. Experiments on the effect of varying temperature on the interaction of $\mathrm{BCG}$ and $\mathrm{FN}$ indicated that the binding reached equilibrium by $1 \mathrm{~h}$ for all temperatures $\left(4,22\right.$ and $37^{\circ} \mathrm{C}$; data not shown). Subsequent binding assays were performed for $1 \mathrm{~h}$ at $22^{\circ} \mathrm{C}$ for convenience.

Fig. 2 shows the effect of varying the $\mathrm{pH}$ on the binding of ${ }^{125} \mathrm{I}-\mathrm{FN}$ to BCG. Optimal binding occurred within a $\mathrm{pH}$ range of 3.0-6.0. An identical optimal $\mathrm{pH}$ range was observed in three separate experiments. Minimal ${ }^{125} \mathrm{I}-\mathrm{FN}$ bound at $\mathrm{pH} 7.0$ or higher, suggesting that the ${ }^{125} \mathrm{I}-$ FN/BCG interaction may be reversible at high $\mathrm{pH}$; this would aid in the purification of the $\mathrm{BCG}$ receptor molecule. To test this hypothesis we determined the effects of high $\mathrm{pH}$ on the reversibility of the ${ }^{125} \mathrm{I}-\mathrm{FN} / \mathrm{BCG}$ interaction. ${ }^{125} \mathrm{I}-\mathrm{FN}$ binding to BCG was carried out at $\mathrm{pH} 6.0$, and the bacterial pellet obtained from centrifugation was resuspended in buffer at $\mathrm{pH} 10.0$ and incubated for various times. Specific ${ }^{125} \mathrm{I}-\mathrm{FN}$ binding was reversible at $\mathrm{pH} 10$, with $>90 \%$ of label released in $24 \mathrm{~h}$ (Fig. $3 \mathrm{~b}$ ). The supernatant obtained after recentrifugation was also analysed for radioactivity and subjected to SDS-PAGE. The gel was dried and autoradiography was performed. The resultant protein band corresponded to that of FN, indicating that the bound label was indeed FN (data not shown). The reversibility of the ${ }^{125} \mathrm{I}$ FN/BCG interaction when the $\mathrm{pH}$ was maintained within the optimal binding range is shown in Fig. 3(a). Less than $20 \%$ of the bound FN was released during $24 \mathrm{~h}$ incubation at $\mathrm{pH} 6.0$.

To test the effect of salt on the binding of BCG to FN, BCG were suspended in buffer solutions ( $\mathrm{pH}$ 6.0) supplemented with 0-3.0 $\mathrm{M}-\mathrm{NaCl}$ (Fig. 4). The specific binding of BCG to

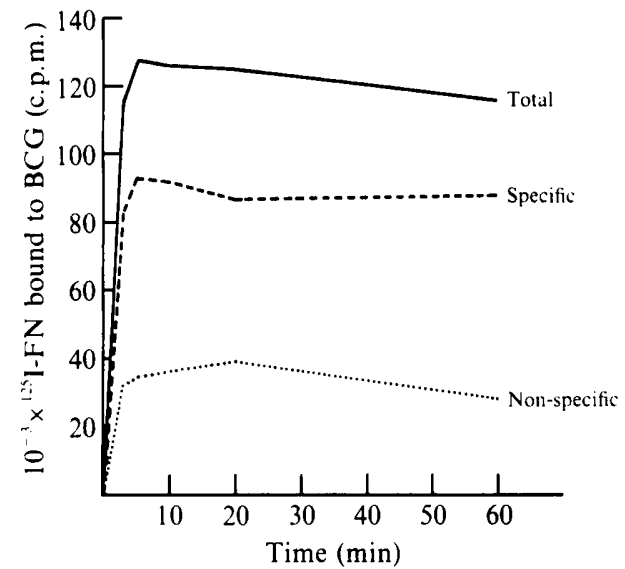

Fig. 1

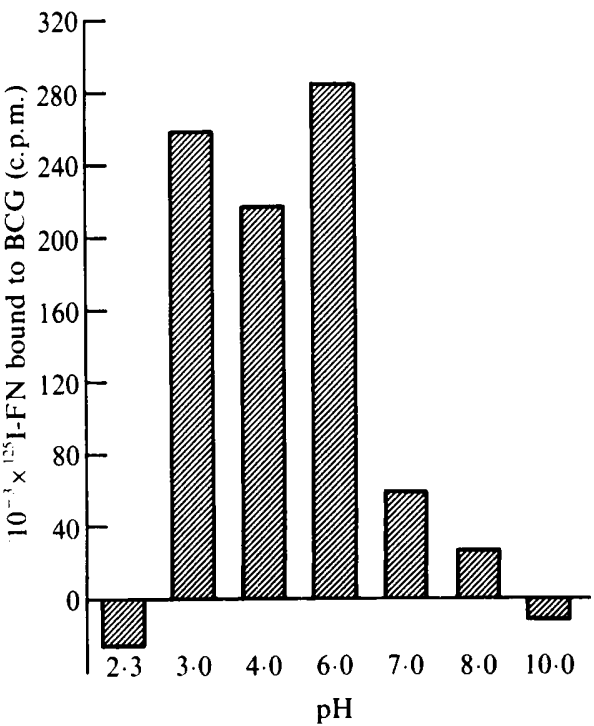

Fig. 2

Fig. 1. Effect of time on the binding of BCG to fibronectin.

Fig. 2. Effect of $\mathrm{pH}$ on the binding of $\mathrm{BCG}$ to fibronectin. 

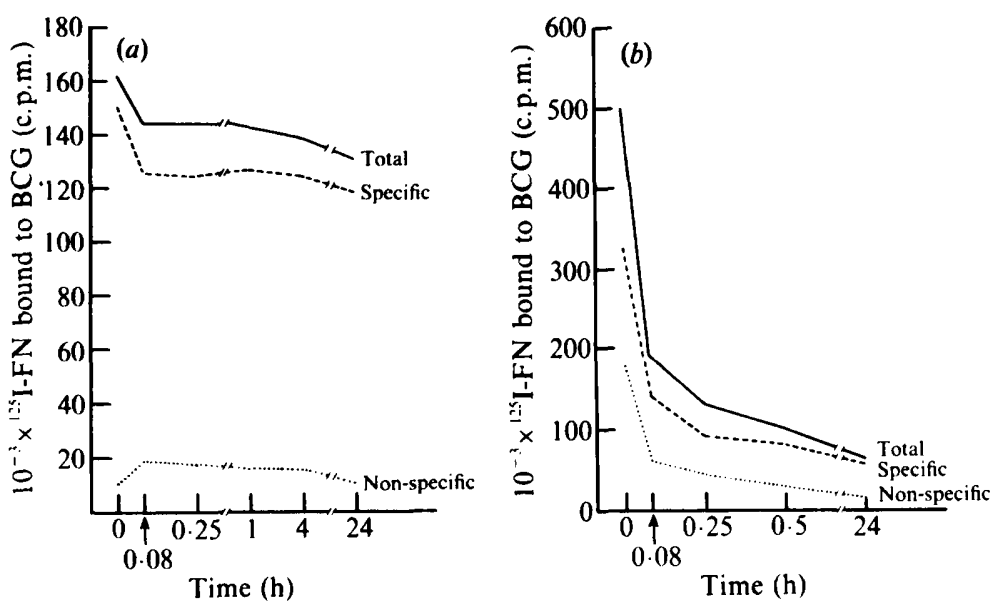

Fig. 3. Reversibility of the binding of BCG to fibronectin during $24 \mathrm{~h}$ incubation at $\mathrm{pH} 6.0(a)$ and pH $10 \cdot 0(b)$.

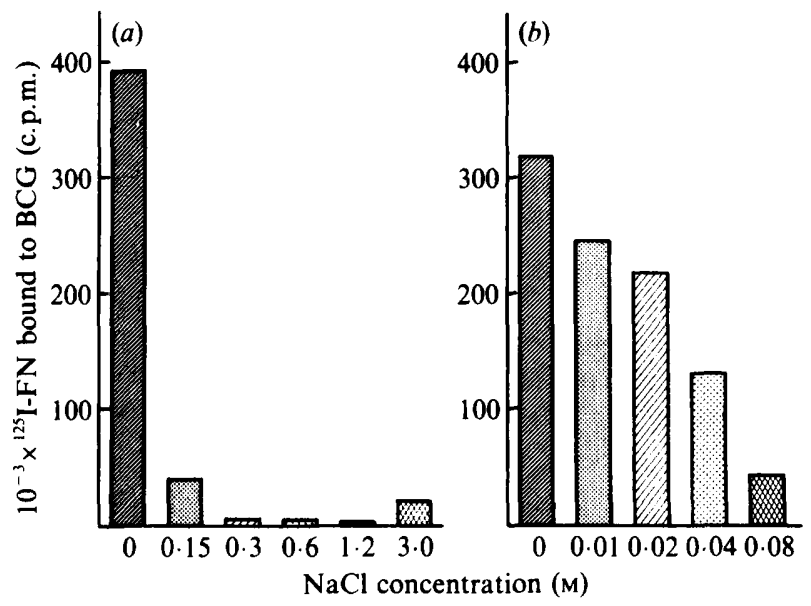

Fig. 4. Effect of $\mathrm{NaCl}$ in the concentration range $0.15-3.0 \mathrm{M}(a)$ and $0.01-0.08 \mathrm{M}(b)$ on the binding of BCG to fibronectin.

FN was inhibited at $\mathrm{NaCl}$ concentrations as low as $0.08 \mathrm{M}$. Similar results were obtained with urine obtained from volunteers. The salt concentrations of the three urine specimens were: (1) 70 $\mathrm{mM}-\mathrm{Na}$; $90 \mathrm{~mm}-\mathrm{K}$; (2) $84 \mathrm{~mm}-\mathrm{Na}, 40.5 \mathrm{~mm}-\mathrm{K}$; (3) $70 \mathrm{~mm}-\mathrm{Na}, 98.8 \mathrm{~mm}-\mathrm{K}$ (data not shown).

In order to determine the saturability of BCG/FN binding a dose-response experiment was conducted utilizing $0-30 \mu \mathrm{g}$ of ${ }^{125} \mathrm{I}-\mathrm{FN}$ in the presence and absence of excess unlabelled FN. The results (Fig. 5) showed that the binding between BCG and FN is dose-dependent and saturable. The number of binding sites per bacterium was ascertained by extrapolation to the asymptote of the dose-response curve. Calculations by this method indicated that approximately 8000 molecules of FN were bound per bacterium. The data were then plotted by the method of Scatchard (Pommier et al., 1984), and the results suggested that there are a maximum of 15000 molecules of FN bound per bacterium (Fig. 5, inset). Furthermore, the appearance of a straight line indicated a single FN receptor on BCG (Scatchard, 1949).

After trypsin pretreatment of BCG, the specific binding of ${ }^{125} \mathrm{I}-\mathrm{FN}$ to BCG was inhibited by $70 \%$, from $56.0 \times 10^{4}$ to $17.7 \times 10^{4}$ c.p.m. These data suggest that the FN receptor on BCG may be a trypsin-sensitive protein. 


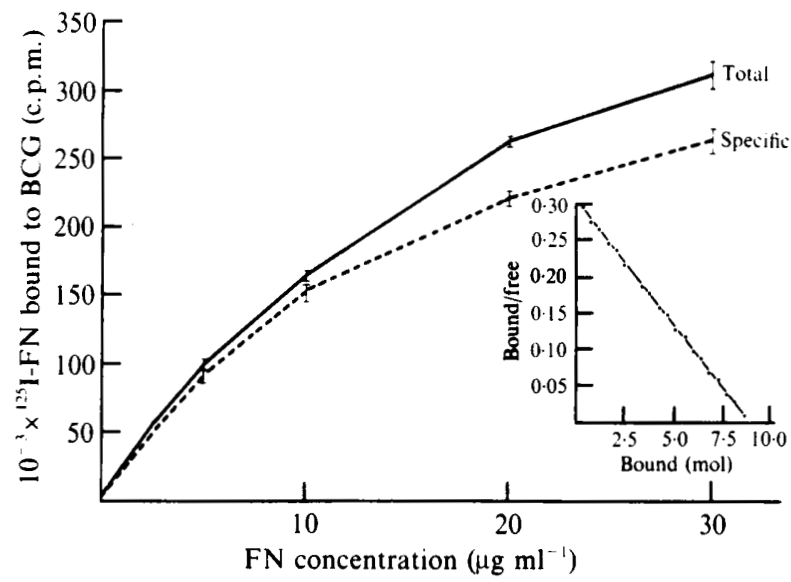

Fig. 5. Saturability of the binding of BCG to fibronectin and (inset) Scatchard analysis of the binding. Bars indicate SEM.

\section{DISCUSSION}

Morales et al. (1976) demonstrated a significant reduction in the recurrence of superficial bladder tumours following combined intravesical and systemic administration of BCG. Since the original observation, BCG has been used extensively for the treatment of superficial bladder cancer and is now considered by many to be the treatment of choice for this disease (Mori et al., 1986). The exact mechanisms by which BCG mediates antitumour activity are not well understood. However, it has been known for many years that BCG is a potent inducer of delayed hypersensitivity and will activate macrophages and cause them to secrete tumour necrosis factors (Old, 1985).

In vitro studies of the interaction between matrix FN and BCG have been studied extensively in our laboratory because of its possible role in adjuvant BCG immunotherapy for superficial bladder cancer. Our results suggest that BCG attachment to FN within the bladder is a requisite step in the initiation of the antitumour response (Ratliff et al., 1987). FN is observed at the basement membrane and in the submucosa but is absent from the apical surface of the urothelium (Pode et al., 1986). Previous in vivo studies have shown that BCG binds specifically to a damaged epithelium where the basement membrane is exposed or a fibrin clot is present (Ratliff et al., 1987). Under such conditions the presence of soluble FN at the site of damage could result in the preferential binding of soluble FN to BCG, which may lower the attachment of BCG to matrix FN in the bladder wall. A potential decrease in attachment could reduce the efficacy of the treatment regimen. Therefore, a better understanding of the interaction between soluble FN and BCG is important for obtaining appropriate clinical results.

The binding of soluble FN to BCG was similar to the interaction previously described for Staphylococcus aureus and Streptococcus pyogenes (Proctor et al., 1982a) in that the interaction was most probably receptor mediated, rapidly saturable, reaching equilibrium within $3 \mathrm{~min}$, and essentially irreversible. Saturation occurred within $1 \mathrm{~h}$ for temperatures ranging from 4 to $37^{\circ} \mathrm{C}$. Furthermore, over $80 \%$ of the bound $\mathrm{FN}$ remained bound at $\mathrm{pH} 6.0$ for at least $24 \mathrm{~h}$ whereas less than $10 \%$ remained bound after $24 \mathrm{~h}$ when the $\mathrm{pH}$ was raised to 10 .

$S$. aureus expresses $7000-30000$ receptors per bacterium, with an association constant of $5 \times 10^{-9} \mathrm{M}$ (Proctor et al., 1982a). Scatchard analysis of the FN/BCG interaction demonstrated similar characteristics. Approximately 8000-15000 receptors per bacterium were observed, and the association constant was approximately $9 \times 10^{-9} \mathrm{M}$. The Scatchard analysis produced a straight line, suggesting that one class of receptor is present.

The FN receptor of $S$. aureus is believed to be a $210 \mathrm{kDa}$ protein which mediates the binding of the organism to a $29 \mathrm{kDa}$ fragment of the molecule at the $\mathrm{NH}_{2}$-terminus (Fröman et al., 1987). $S$. pyogenes type M5 was clearly shown to bind to a fatty acid binding site on the molecule 
through lipoteichoic acid present on the bacterial cell wall (Courtney et al., 1983). However, a different strain of this organism, $S$. pyogenes 1321, was shown to bind to FN through a trypsinextractable and papain-sensitive surface protein (Speziale et al., 1984). The matrix FN receptor of BCG has been previously shown to be a trypsin-sensitive protein (Ratliff et al., 1988). The loss of the ability of BCG to bind soluble FN after treatment with the protease trypsin indicated that the soluble FN receptor on BCG was also trypsin-sensitive, suggesting that it may be a protein. However, no attempt was made to investigate the structure or composition of this receptor further, or its relationship to the matrix form of the $\mathrm{FN}$ receptor.

Binding of FN to BCG differed from that of $S$. aureus in several ways. Proctor et al. (1982a) showed that $\mathrm{NaCl}$ enhanced the interaction between $S$. aureus and $\mathrm{FN}$. In contrast, FN binding to $\mathrm{BCG}$ was inhibited by the presence of as little as $0.08 \mathrm{M}-\mathrm{NaCl}$. The inhibitory effects of $\mathrm{NaCl}$ were uniformly observed over the optimal $\mathrm{pH}$ range of 3-6. In addition, the $\mathrm{pH}$ range for $\mathrm{FN}$ binding to BCG differed from that observed for $S$. aureus. BCG bound optimally to FN at an acidic $\mathrm{pH}$ ( $\mathrm{pH}$ range $3-6$ ), and a low level of binding occurred at neutral or basic $\mathrm{pH}$. The optimal pH observed for $S$. aureus was 6.0 but binding was absent below pH 5.0 (Proctor et al., $1982 a$ ). Significant ${ }^{125} \mathrm{I}-\mathrm{FN}$ binding was observed for BCG at $\mathrm{pH} 3.0$. The inhibitory effect of $\mathrm{pH}$ and salt on the binding of soluble FN to BCG was not observed for the interaction between BCG and matrix FN (data not shown). The reason for the differences is not known.

FN bound to BCG at low pH could be eluted by reincubation of the organism at higher $\mathrm{pH}$. This property of the BCG/FN interaction was utilized to elute radiolabelled FN from BCG. The eluted protein was subjected to gel electrophoresis and autoradiography to demonstrate that the bound label was indeed FN (data not shown).

Since urine contains significant salt levels, the ${ }^{125}$ I-FN binding assay was performed in the presence of human urine to determine its effect on the binding of soluble FN to BCG. Urine inhibited ${ }^{125} \mathrm{I}-\mathrm{FN}$ binding to BCG. The inhibition may have been associated with the salt concentration. Previous work in our laboratory has shown that urine does not interfere with the binding of BCG to matrix FN (data not shown). Moreover, unpublished data show that binding of soluble FN to BCG prior to intravesical instillation inhibits attachment of BCG to the bladder wall. These data suggest that the diluent for BCG should have a neutral or basic $\mathrm{pH}$ and should be supplemented with a minimum of $0.08 \mathrm{M}-\mathrm{NaCl}$. Such a diluent would decrease the potential inhibition of BCG attachment to the bladder wall by minimizing the binding of soluble FN.

In conclusion, the binding of ${ }^{125}$ I-FN to BCG appears to be receptor-mediated. A single class of receptors is present and it is most probably protein in nature. The interaction between ${ }^{125} \mathrm{I}$ FN and BCG is saturable and essentially irreversible with an association constant of $9 \times 10^{-9} \mathrm{M}$. Approximately $8000-15000$ receptors are present on each bacterium. Both salt and basic pH inhibit binding. Studies are in progress to characterize the BCG receptor more clearly.

This work was supported by USPHS Grant CA37926 and CA44426 from the National Cancer Institute through the National Bladder Cancer Project.

\section{REFERENCES}

Catalona, W. J., Hudson, M. A., Gillen, D. P., ANDRIOLE, G. L. \& RATLIFF, T. L. (1987). Risks and benefits of repeated courses of intravesical bacillus Calmette-Guérin therapy for superficial bladder cancer. Journal of Urology 137, 220-224.

Courtney, H. S., Ofek, I., Simpson, W. A., Hasty, D. L. \& BEACHEY, E. H. (1983). Binding of Streptococcus pyogenes to soluble and insoluble fibronectin. Infection and Immunity 53, 454-459.

Fröman, G., Switalski, L. M., Speziale, P. \& Höök, M. (1987). Isolation and characterization of a fibronectin receptor from Staphylococcus aureus. Journal of Biological Chemistry 262, 6564-6571.

HYNes, R. O. \& YAMAD, K. M. (1982). Fibronectins: multifunctional modular glycoproteins. Journal of Cellular Biology 95, 369-377.

Morales, E., Eidinger, D. \& Bruce, A. W. (1976). Intracavitary bacillus Calmette-Guérin in the treatment of superficial bladder tumors. Journal of Urology 116, 180-183.

Mori, K., Lamm, D. L. \& Crawford, E. D. (1986). A trial of bacillus Calmette-Guérin versus Adria- 
mycin in superficial bladder cancer. A South-west Oncology Group Study. Urology International 41, 254-259.

Mosher, D. F. (1980). Fibronectin. Progress in Hematology and Thrombosis 5, 111-151.

OLD, L. J. (1985). Tumor necrosis factor (TNF). Science 230, 630-632.

Pode, D., Alon, Y., Horowitz, A. T., Vlodavsky, I. \& BIRAN, S. (1986). The mechanism of human bladder tumor implantation in an in vitro model. Journal of Urology 136, 482-486.

Pommier, C. G., Oshea, J., Chused, T., Yancey, K., Frank, M. M., Takahashi, T. \& Brown, E. J. (1984). Studies on the fibronectin receptors of human peripheral blood leukocytes. Journal of Experimental Medicine 159, 137-151.

Proctor, R. S., Mosher, D. F. \& Olbrantz, P. J. (1982a). Fibronectin binding to Staphylococcus aureus. Journal of Biological Chemistry 257, 14788-14794.

Proctor, R., Prendergast E. \& Mosher, D. F. $(1982 b)$. Fibronectin mediates attachment of Staphylococcus aureus to human neutrophils. Blood 59, 681-687.
Ratliff, T. L., Palmer, J. O., McGarr, J. A. \& Brown, E. J. (1987). Intravesical bacille CalmetteGuérin (BCG) therapy for murine bladder tumors: initiation of the response by fibronectin mediated attachment of BCG. Cancer Research 47, 1762-1766.

Ratliff, T. L., MCGarR, J. A., AbOU-Zeid, C., RoOK, G. A. W., Stanford, J. L., Aslanzadeh, J. \& Brown, E. J. (1988). Attachment of mycobacteria to fibronectin-coated surfaces. Journal of General Microbiology 134, 1307-1313.

SCATCHARD, G. (1949). The attractions of proteins for small molecules and ions. Annals of the New York Academy of Sciences 51, 660-672.

Speziale, P., HööK, M., Switalski, L. M. \& WadSTRÖM, T. (1984). Fibronectin binding to a Streptococcus pyogenes strain. Journal of Bacteriology 157, 420-427.

WIRTH, J. J. \& KIERSZENBAUM, F. (1984). Fibronectin enhances association with invasive forms of Trypanosoma cruzi. Journal of Immunology 133, 460-464. 